(RESEARCH ARTICLE)

\title{
Potential of Centella asiatica leaf extract in the management of paracetamol-induced jaundice in albino rats
}

\author{
Ogunka-Nnoka Charity Uchechi ${ }^{1, *}$, Igwe Felix Uchenna ${ }^{2}$, Ovuworie Fegor Precious ${ }^{1}$, Eme Lilian Olu${ }^{1}$ and \\ Niabari Bariburame ${ }^{1}$
}

${ }^{1}$ Department of Biochemistry, University of Port Harcourt, Choba, Rivers State, Nigeria.

${ }^{2}$ Department of Biochemistry, Rivers State University, Port Harcourt, Rivers State, Nigeria.

Publication history: Received on 23 April 2020; revised on 28 April 2020; accepted on 29 April 2020

Article DOI: https://doi.org/10.30574/wjarr.2020.6.1.0122

\begin{abstract}
Jaundice is a condition associated with the imbalance between bilirubin production and excretion when the liver is diseased. This study investigated the Potential of Centella asiatica leaf extract in the management of paracetamolinduced jaundice in albino rats. The rats were randomly distributed into six groups of five each. Group 1 (normal control- fed with rat feed and water), group 2 (paracetamol $2 \mathrm{~g} / \mathrm{kg}$ body weight), group 3 (paracetamol $2 \mathrm{~g} / \mathrm{kg}$ bw + silymarin $100 \mathrm{mg} / \mathrm{kg} \mathrm{bw})$ and groups $4-6(2 \mathrm{~g} / \mathrm{kg}$ bw each $+200,400$ and $600 \mathrm{mg} / \mathrm{kg}$ bw of CaL- extract respectively). The Paracetamol was first administered to the rats for 5 days to establish jaundice followed by administration of silymarin and CaL- extract for 10 days before sacrifice. The group 2 (negative control) rats had significant increase $(\mathrm{p}<0.05)$ in glucose level $(7.50 \pm 0.10 \mathrm{mmol} / \mathrm{L})$ and haematological parameters like haemoglobin $(8.65 \pm 0.15 \mathrm{~g} / \mathrm{dL})$, packed cell volume $(26.15 \pm 0.95 \%)$, red blood cell $\left(3.75 \pm 0.05 \times 10^{12} / \mathrm{L}\right)$ and platelet $\left(248.00 \pm 1.00 \times 10^{9} / \mathrm{L}\right)$ as well as elevated levels of serum lipids (LDL, TG,TC VLDL-cholesterol) when compared with group 3 and the CaL-treated groups. Results of the liver function maker enzymes (AST, ALT and ALP) activity, serum bilirubin and proteins as well as renal function indices (creatinine, urea, chloride and bicarbonate) in group 2 were significantly increased $(\mathrm{p}<0.05)$; while endogenous antioxidant study, revealed low levels of catalase $(1.24 \pm 0.02 \mu \mathrm{mol} / \mathrm{ml})$, superoxide dismutase $(0.17 \pm 0.02 \mathrm{unit} / \mathrm{ml})$ and reduced glutathione $(0.84 \pm 0.18 \mathrm{mg} / \mathrm{ml})$ when compared to the treated groups. Administration of the CaL-extract and silymarin ameliorated the paracetamol-induced jaundice in albino rats.
\end{abstract}

Keywords: Potential; Jaundice; Centella asiatica leaf; Extract; Paracetamol; Albino rats

\section{Introduction}

The growing interest in the use of herbal medicine demands information on the various herbal preparations. Scientific evaluation of medicinal plants could play a pivotal role in the discovery of novel drugs and elucidation of toxic risks associated with the use of herbal preparations and other conventional drugs of plant origin in the treatment of diseases [1]. Herbal remedies, especially in the form of teas or extracts, used for the treatment of various diseases are gaining increasing popularity. This is mostly attributed to their potency and availability [2]. Phytomedicines are currently recognized as the most common form of alternative medicine used by about $60 \%$ of the world population both in the developing and in the developed countries where modern medicines are predominantly in use [3]. The use of plant in combating various pathological conditions is solely due to their rich abundances of various phytochemicals. It is believed that these compounds possess medicinal properties capable of ameliorating disease conditions [4, 5]. As a result of the emergence of diseases and their associated conditions, there is need to investigate the potentials of some underutilized medicinal plants.

Centella asiatica is a herbaceous plant commonly known as"Gotu Kola", "Asiatic pennywort", "Indian pennywort" or "Spadeleaf" and belongs to the familyApiaceae [6].It is found in most tropical and subtropical countries growing in

*Corresponding author: Ogunka-Nnoka Charity Uchechi

Copyright (C) 2020 Author(s) retain the copyright of this article. This article is published under the terms of the Creative Commons Attribution Liscense 4.0. 
swampy areas, including parts of India, Pakistan, Sri Lanka, Madagascar, South Africa, South pacific and Eastern Europe. It is a tasteless, odourless plant that thrives in and around water. It has small fan-shaped green leaves with white or light purple-to-pink flowers and it bears small oval fruit. The plant has long been used as vegetable in China, Southeast Asia, India, Sri Lanka, Oceania, and Africa. In South-east Asia, it is traditionally used for the treatment of a wide variety of disorders such as skin diseases, rheumatism, inflammation, syphilis, mental illness, jaundice, epilepsy, hysteria, dehydration, and diarrhea [7]. Centella asiatica (Gotu kola) is known as longevity herb and used widely in India and Nepal as part of the traditional Ayurvedic medicine. Its roots and leaves are used for medicinal purposes and provide important health benefits related to healthy veins and blood vessels, to treat skin disorders, help with better memory and improve brain function [8]. It is ranked high in the top ten herbs known for anti-aging properties and this may be in part due to its anti-oxidative effects. It also possesses neurotonic effects and is known to improve memory and stimulus reflex[9].Administration of Gotu kola extract is shown to be effective in preventing oxidation of proteins, lipid peroxidation, and pro-oxidant processes with a concomitant increase in the antioxidant enzymes activity[10].

Physiological ranges of blood biochemistry parameters differ substantially for each animal species. Assessments of biochemical parameters in metabolic profiling are of great importance in healthcare. In clinically healthy animals, alterations in metabolic profile parameters can occur, despite the absence of visible symptoms. The results of biochemical analysis show economic validity and represent a significant contribution to monitoring the health status. The liver is a sensitive organ that is susceptible to pollutants and drugs alike. Most researchers have shown that jaundice rank high among most conditions that present patients with liver and billiary toxicity [11, 12]. Jaundice is one of the most common medical conditions affecting people of all ages, especially neonates. It is not a disease but a visible sign and symptom of an underlying disease which occurs when there is increase in the amount of bilirubin circulating in blood. It is associated with the appearance of yellow pigmentation in the skin, sclera and mucous membranes [12]. Hepatic jaundice is a type of jaundice in which the basic defect lies within the liver mainly in the hepatocytes. Any condition in the liver leading to defect in excretion of bilirubin can cause hepatic jaundice. Administration of ethanol extract of Anthocleista vogelii ameliorated the jaundiced condition in experimental rats [11]. Due to a regular occurrence of jaundice in more than $60 \%$ of neonatal babies during the first seven days of life, it becomes necessary to further investigate the potentials of ethanol extract of Gotu kola (Centella asiatica) leaves in the treatment of jaundice following paracetamol- induced hepatotoxicity in albino rats.

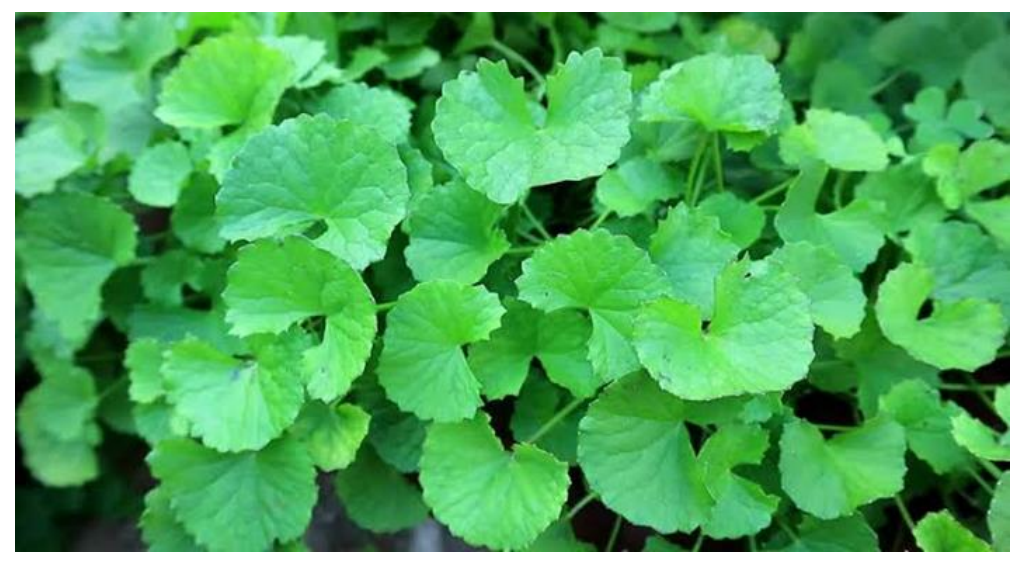

Figure 1: Centella asiatica (Gotu kola) leaves (Source: herbalstreatments.blogspot.com)

\section{Material and methods}

\subsection{Collection and identification of plant material}

Fresh leaf samples of Gotu kola were obtained from a swampy area in Bonny, Rivers State, Nigeria and were identified and authenticated by Dr.C. Ekeke, a plant Taxonomist in the Department of Plant Science and Biotechnology, University of Port Harcourt, Rivers State, Nigeria. The samples were taken to the laboratory to be prepared for analysis.

\subsection{Acclimatization of animals}

Thirty Albino rats (140-200g) obtained from the animal house of the Faculty of Basic Medical Sciences, University of Port Harcourt, Port Harcourt, Nigeria were housed in a well-ventilated animal house with free access to feed and water ad libtum for 7 days before commencement of the study. This was done to allow the albino rats adapt properly to the new environment. 


\subsection{Preparation of plant sample and extraction}

Fresh leaves samples of Centella asiatica were sorted, cleaned, dried at room temperature $\left(25-28^{\circ} \mathrm{C}\right)$ for 14 days and blended using electric blender. The blended sample was sieved using a $100 \mathrm{~mm}$ mesh screen to obtain fine powdered sample. The powdered sample was neatly packed in an airtight glass sample container and subsequently used for extraction. Extraction was carried out by measuring $600 \mathrm{~g}$ of the powdered leaves sample into $1000 \mathrm{ml}$ of $80 \%$ ethanol using cold maceration method for 24 hours. The extract was filtered through cheese cloth with fine pore, and the filtrate was further filtered using Whatman No. 1 filter paper. The resulting extract was then concentrated at $50^{\circ} \mathrm{C}$ in a rotary evaporator for 2 hours and transferred to a water bath maintained at $40^{\circ} \mathrm{C}$ and evaporated to dryness yielding a dark green mass. The dried extract obtained was weighed, transferred into an airtight glass container and stored at $4^{\circ} \mathrm{C}$ until when required for use. The percentage yield of the extract was calculated using the formula:

$$
\% \text { Yield }=\frac{\text { weight of extract }}{\text { weight of sample }} \times \frac{100}{1}
$$

\subsection{Induction of jaundice}

Liver damage (hepatotoxicity) was induced by administering paracetamol ( $2 \mathrm{~g} / \mathrm{kg}$ bw) orally for five (5) days after the rats were fasted for 12 hours. Each rat in the normal control group was administered with normal saline solution. The presence of hepatotoxicity, as manifested by jaundice was confirmed by physical observation of yellowish colour in the eyes/skin pigmentation and level of bilirubin [13].

\subsection{Experimental design}

Thirty (30) wistar albino rats of both sexes were used in the study. They were randomly divided into 6 groups containing 5 rats in each group.

Group 1: Rats that received normal saline solution orally (Normal control).

Group 2: Rats that received $2 \mathrm{~g} / \mathrm{kg}$ body weight of Paracetamol orally (Negativecontrol).

Group 3: Rats that received $2 \mathrm{~g} / \mathrm{kg}$ body weight of Paracetamol $+100 \mathrm{mg} / \mathrm{kg}$ body weight of Silymarin orally (Positive control).

Group 4: Rats that received $2 \mathrm{~g} / \mathrm{kg}$ body weight of Paracetamol $+200 \mathrm{mg} / \mathrm{kg}$ body weight of ethanol leaf extract of Centella asiatica orally.

Group 5: Rats that received $2 \mathrm{~g} / \mathrm{kg}$ body weight of Paracetamol $+400 \mathrm{mg} / \mathrm{kg}$ body weight of ethanol leaf extract of Centella asiatica orally.

Group 6: Rats that received 2g/kg body weight of Paracetamol $+600 \mathrm{mg} / \mathrm{kg}$ body weight of ethanol leaf extract of Centella asiatica orally.

The ethanol extract treatment dosage was administered as described by Ekor [14].

\subsection{Collection and preparation of blood samples and tissue homogenate}

The study period lasted for 15days; after which the rats were fasted for $12 \mathrm{hrs}$ and sacrificed by cervical decapitation. Each rat was placed on dorsal surface, and a laparotomy was carried out to expose the internal organs. Blood samples were collected in plain EDTA tubes and allowed to clot and the serum separated by centrifuging at 3000rpm for 10 minutes. The sera collected were stored at $4^{\circ} \mathrm{C}$ until required for the various biochemical analyses conducted.

Also, a portion of the liver $(0.5 \mathrm{~g})$ was collected, rinsed with cold saline, weighed and homogenized in $4.5 \mathrm{ml}$ of $0.1 \mathrm{M}$ cold phosphate buffer using mortar and pestle immersed in ice. A $0.5 \mathrm{~g}$ of the cleaned liver organ was homogenized in $4.5 \mathrm{ml}$ of $0.1 \mathrm{M}$ phosphate buffer ( $\mathrm{pH} 7.4$ ). The homogenate was then transferred into a plane tube and centrifuged. The resultant supernatant was subsequently used for various biochemical analyses conducted on the liver.

\subsection{Determination of glucose}

Glucose was determined in the serum using glucose oxidase method as described by Drucker et al.,[15].MultiCarein ${ }^{\mathrm{TM}}$ glucose strips and glucometer were used. 


\subsection{Determination of lipid profile}

Plasma total cholesterol, triglycerides, and high density lipoproteins (HDL) were determined enzymatically using commercially available kits (Randox kits). From the results, LDL cholesterol was calculated using the formula of Friedelwald et al.,[16].

\subsection{Determination of hematological indices}

The Packed Cell Volumes (PCV), White Blood Cell (WBC) counts, Red Blood Cell (RBC) counts, Hemoglobin (Hb) Concentrations, and platelets counts, were obtained using an Automated Hematology Analyzer (MC-2800) manufactured by Mindray Company, China.

\subsection{Determination of liver function indices}

Determination of liver enzymes and other biochemical indices were done using Prietest Easylab Biochemistry Analyzer [17].

\subsection{Determination of kidney function indices}

Kidney function indices were analyzed from the serum sample. Serum urea concentration was determined by the diacetyl monoxime method using assay kit from Randox laboratories UK, while creatinine concentration was determined by the alkaline picrate method [18].

Serum sodium and potassium concentrations were determined using the requisitereagent kit[18].Serum bicarbonate concentration was determined titrimetrically while mercuric nitrate method was used to determinethe concentration of chloride as modified by Tecodiagnostics1268N Lakeview Avenue Anahein; CA 92807, USA [19].

\subsection{Determination of hepatic antioxidant markers}

\subsubsection{Determination of catalase (CAT) activity:}

Fifty microliters $(50 \mu \mathrm{L})$ of the liver homogenate sample was added to a cuvette containing $2 \mathrm{ml}$ of $0.05 \mathrm{M}$ phosphate buffer ( $\mathrm{pH} \mathrm{7.4)}$ and $1 \mathrm{ml}$ of $30 \mathrm{mM} \mathrm{H}_{2} \mathrm{O}_{2}$ and the absorbance was read at $240 \mathrm{~nm}$ for 3 minutes at 30 seconds interval using spectrophotometer[20].

\subsubsection{Determination of super oxide dismutase (SOD) activity}

Super oxide dismutase activity was determined according toMisra and Fridovich [21]. A $0.2 \mathrm{ml} \mathrm{liver} \mathrm{homogenate} \mathrm{sample}$ was added to $2.5 \mathrm{ml} 0.05 \mathrm{M}$ bicarbonate buffer $(\mathrm{pH} \mathrm{10.2)}$ and used as test sample while for reference $0.2 \mathrm{ml}$ of distilled water was used in place of the sample. Then $0.3 \mathrm{ml}$ of $0.3 \mathrm{mM}$ adrenaline solution was added and the absorbance was read immediately at $420 \mathrm{~nm}$ for 3minutes at 1 minute interval. The SOD activity was estimated using the formula:

\% Inhibition=[O.D.Reference -O.D.Test/O.D.Reference]

SOD activity (Units/g tissue)=[\% inhibition/50 $\times$ tissue weight $(\mathrm{g})]$

\subsubsection{Determination of total reduced glutathione (GSH)}

Total reduced glutathione (GSH) was determined in the liver homogenate according to Moron et al., [22].A $0.5 \mathrm{ml}$ sample was precipitated with $2.0 \mathrm{ml} 5 \%$ TCA. $1.0 \mathrm{ml}$ of supernatant was taken after centrifugation and $0.5 \mathrm{ml}$ of Ellman's reagent and $3.0 \mathrm{ml}$ of phosphate buffer was added to all the tubes. The absorbance was read at $412 \mathrm{~nm}$ within 2 minutes against the reagent blank. The amount of glutathione was expressed as $\mu \mathrm{g} / \mathrm{g}$ tissue.

\subsubsection{Estimation of malondialdehyde}

The malondialdehyde was estimated according to Niehius and Samuelsson [23].One milliliter (1.0 ml) liverhomogenate was added into a test tube labeled test and $1.0 \mathrm{ml}$ of distilled water was into another tube labeled as blank. The TBATCA-HClreagent mixture of $2.0 \mathrm{ml}$ was added to all test tubes. All the tubes were mixed well and placed in boiling water bath for 15 minutes,cooled and centrifuged at $2000 \mathrm{rpm}$ for 10 minutes. The absorbance of the supernatant was measured at $535 \mathrm{~nm}$. The malondialdehyde concentration of the sample was calculated using the extinction coefficient of $1.56 \times 10^{5} \mathrm{~m}^{-1} \mathrm{~cm}^{-1}$. 


\subsection{Statistical analysis}

All data were analyzed using Statistical Package for Social Sciences (SPSS) version 20.0 (IBM Statistics, UK). Values were reported as means \pm standard error of mean (SEM) and one way ANOVA was used to test for differences between treatment groups. The results were considered significant at $95 \%$ confidence level $(\mathrm{p}<0.05)$.

\section{Results and discussion}

Following induction of jaundice, it was observed from the results (Table 1) that the glucose level Group 2 were significantly $(\mathrm{p}<0.05)$ increased $(7.50 \pm 0.10 \mathrm{mmol} / \mathrm{L})$, when compared to the normal control $(5.80 \pm 0.40 \mathrm{mmol} / \mathrm{L})$. Jaundiced rats treated with $100 \mathrm{mg}$ of silymarin (Group 3) and the groups administered with CaL-extract were observed to have significant decrease $(\mathrm{p}<0.05)$ in glucose level when compared to jaundiced rats (Group 2).

Table 1: Effect of administration of ethanol extract of Centella asiatica leaves on blood glucose concentration in paracetamol- induced jaundiced albino rats

\begin{tabular}{ll}
\hline Group & Glucose $(\mathbf{m m o l} / \mathbf{L})$ \\
\hline 1 (NC) & $5.80 \pm 0.40^{\mathrm{b}}$ \\
2 (NGC) & $7.50 \pm 0.10^{\mathrm{c}}$ \\
3 (PC) & $5.45 \pm 0.25^{\mathrm{b}}$ \\
$4(200 \mathrm{mg})$ & $3.75 \pm 0.35^{\mathrm{a}}$ \\
$5(400 \mathrm{mg})$ & $3.90 \pm 0.20^{\mathrm{a}}$ \\
$6(600 \mathrm{mg})$ & $5.15 \pm 0.05^{\mathrm{a}, \mathrm{b}}$ \\
\hline
\end{tabular}

Values are means \pm Standard error of mean (SEM) and $n=2$. Mean with different superscripts in a column are significantly different(p<0.05).

$*$ NC $=$ Normal Control, PC $=$ Positive Control, NGC = Negative Control, CaL = Centellaasiatica leaves.

The result in Table 2 shows that the lipid profile parameters of jaundiced rats (Group 2) increased except for HDL (which was decreased) when compared to group 3 and the CaL-extract treated groups. The increase was significant ( $<<0.05$ ) with respect to Very Low Density Lipoprotein- cholesterol and Triglyceride. High Density Lipoprotein levels for groups 1, 3 and 4-6 increased significantly $(\mathrm{p}<0.05)$ when compared to group 2.

Table 2: Effect of administration of ethanol extract of Centella Asiatica leaves on lipid profile (mmol/L) of paracetamol -induced jaundiced albino rats.

\begin{tabular}{llllll}
\hline Group & TC & TG & HDL-C & LDL-C & VLDL-C \\
\hline $1(\mathrm{NC})$ & $2.25 \pm 0.05^{\mathrm{a}}$ & $0.87 \pm 0.04^{\mathrm{a}, \mathrm{b}}$ & $0.82 \pm 0.03^{\mathrm{b}}$ & $1.36 \pm 0.04^{\mathrm{a}, \mathrm{b}, \mathrm{c}}$ & $0.40 \pm 0.02^{\mathrm{a}}$ \\
$2(\mathrm{NGC})$ & $2.85 \pm 0.15^{\mathrm{a}, \mathrm{b}}$ & $1.17 \pm 0.12^{\mathrm{b}}$ & $0.50 \pm 0.07^{\mathrm{a}}$ & $1.42 \pm 0.15^{\mathrm{a}, \mathrm{b}, \mathrm{c}}$ & $0.53 \pm 0.05^{\mathrm{b}}$ \\
$3(\mathrm{PC})$ & $2.15 \pm 0.15^{\mathrm{a}}$ & $0.97 \pm 0.06^{\mathrm{a}, \mathrm{b}}$ & $0.83 \pm 0.03^{\mathrm{b}}$ & $0.91 \pm 0.11^{\mathrm{a}, \mathrm{b}}$ & $0.23 \pm 0.23^{\mathrm{a}}$ \\
$4(200 \mathrm{mg})$ & $2.27 \pm 0.40^{\mathrm{a}}$ & $0.97 \pm 0.12^{\mathrm{a}, \mathrm{b}}$ & $1.04 \pm 0.23^{\mathrm{c}}$ & $0.79 \pm 0.01^{\mathrm{a}}$ & $0.45 \pm 0.06^{\mathrm{a}}$ \\
$5(400 \mathrm{mg})$ & $2.78 \pm 0.35^{\mathrm{a}, \mathrm{b}}$ & $0.74 \pm 0.01^{\mathrm{a}}$ & $1.18 \pm 0.20^{\mathrm{c}}$ & $1.57 \pm 0.20^{\mathrm{c}}$ & $0.34 \pm 0.01^{\mathrm{a}}$ \\
$6(600 \mathrm{mg})$ & $3.48 \pm 0.03^{\mathrm{b}}$ & $1.25 \pm 0.05^{\mathrm{b}}$ & $1.18 \pm 0.01^{\mathrm{c}}$ & $1.50 \pm 0.01^{\mathrm{b}, \mathrm{c}}$ & $0.57 \pm 0.02^{\mathrm{a}}$ \\
\hline
\end{tabular}

Values are means \pm Standard error of mean (SEM) and $\mathrm{n}=2$. Mean with different superscripts in a column are significantly different $(\mathrm{p}<0.05)$. $N C=$ Normal Control, $P C=$ Positive Control,$N G C=$ Negative Control, $C a L=$ Centella asiatica leaves.

Effect of ethanol leaf extract of Centella asiaticaon heamatological indices are shown in Table 3. There was no significant difference in PCV, $\mathrm{Hb}$ and RBC, levels in groups 1, 3and all extract treated groups; but there was significant decrease in $\mathrm{PCV}, \mathrm{Hb}$ and RBC of group 2 rats as compared to group 3 and groups 4-6. Administration of CaL-extract increased the levels of PCV,HB and RBC. There was significant increase in WBC level of groups 2-6 when compared to group 1(normal control). 
Table 3: Effect of administration of ethanol extract of Centella asiatica leaves on some haematological parameters of paracetamol-induced jaundiced albino rats

\begin{tabular}{llllll}
\hline Group & HB (g/dL) & PCV (\%) & RBC $(\mathbf{x ~ 1 0 1 2} / \mathbf{L})$ & WBC $(\mathbf{x ~ 1 0} / \mathbf{L})$ & PLT (x109/L) \\
\hline 1 (NC) & $13.10 \pm 0.40^{\mathrm{b}}$ & $38.50 \pm 0.50^{\mathrm{c}}$ & $5.65 \pm 0.15^{\mathrm{b}}$ & $9.15 \pm 0.65^{\mathrm{a}}$ & $189.00 \pm 6.00^{\mathrm{a}}$ \\
$2(\mathrm{NGC})$ & $8.65 \pm 0.15^{\mathrm{a}}$ & $26.15 \pm 0.95^{\mathrm{a}}$ & $3.75 \pm 0.05^{\mathrm{a}}$ & $12.30 \pm 0.20^{\mathrm{b}}$ & $248.00 \pm 1.00^{\mathrm{b}}$ \\
$3(\mathrm{PC})$ & $12.15 \pm 0.01^{\mathrm{b}}$ & $36.85 \pm 1.05^{\mathrm{b}, \mathrm{c}}$ & $5.15 \pm 0.05^{\mathrm{b}}$ & $13.65 \pm 0.05^{\mathrm{b}}$ & $267.50 \pm 2.50^{\mathrm{b}}$ \\
$4(200 \mathrm{mg})$ & $14.45 \pm 0.05^{\mathrm{c}}$ & $31.15 \pm 0.45^{\mathrm{a}, \mathrm{b}, \mathrm{c}}$ & $5.15 \pm 0.05^{\mathrm{b}}$ & $16.85 \pm 2.05^{\mathrm{c}}$ & $447.50 \pm 51.50^{\mathrm{c}}$ \\
$5(400 \mathrm{mg})$ & $14.95 \pm 0.35^{\mathrm{c}}$ & $30.80 \pm 2.90^{\mathrm{a}, \mathrm{b}}$ & $5.35 \pm 0.25^{\mathrm{b}}$ & $14.40 \pm 1.60^{\mathrm{a}, \mathrm{b}}$ & $416.00 \pm 101.00^{\mathrm{c}}$ \\
$6(600 \mathrm{mg})$ & $14.75 \pm 0.05^{\mathrm{c}}$ & $30.63 \pm 0.03^{\mathrm{a}, \mathrm{b}}$ & $5.45 \pm 0.05^{\mathrm{b}}$ & $27.95 \pm 2.05^{\mathrm{d}}$ & $436.00 \pm 2.00^{\mathrm{c}}$ \\
\hline
\end{tabular}

Values are means \pm Standard error of mean (SEM) and $\mathrm{n}=2$. Mean with different superscripts in a column are significantly different $(\mathrm{p}<0.05)$.

$N C=$ Normal Control, $P C=$ Positive Control, $N G C=$ Negative Control, CaL = Centella asiatica leaves.

Endogenous antioxidants markers such as Catalase (CAT), Superoxide Dismutase (SOD) and reduced glutathione (GSH) activities were significantly increased $(\mathrm{p}<0.05)$ although not in a dose-dependent manner in all groups administered with the extract when compared to group 2 (Table 4). The result also showed an increase in Malondialdehyde (MDA) in groups 2, 5 and 6 when compared to groups 1 and 4 .

Table 4 Effect of administration of ethanol extract of Centella asiatica leaves on in vivo antioxidants of paracetamolinduced jaundiced albino rats

\begin{tabular}{lllll}
\hline Group & GSH $(\mathbf{m g} / \mathbf{m l})$ & CAT $(\boldsymbol{\mu m o l} / \mathbf{m l})$ & SOD $($ unit $/ \mathbf{m l})$ & MDA $(\boldsymbol{\mu m o l} / \mathbf{m l})$ \\
\hline $1(\mathrm{NC})$ & $1.42 \pm 0.04^{\mathrm{c}}$ & $2.42 \pm 0.06^{\mathrm{a}, \mathrm{b}}$ & $0.71 \pm 0.01^{\mathrm{d}}$ & $0.28 \pm 0.01^{\mathrm{a}}$ \\
$2(\mathrm{NGC})$ & $0.84 \pm 0.18^{\mathrm{a}}$ & $1.24 \pm 0.02^{\mathrm{a}}$ & $0.21 \pm 0.11^{\mathrm{a}, \mathrm{b}}$ & $0.55 \pm 0.02^{\mathrm{b}}$ \\
$3(\mathrm{PC})$ & $1.33 \pm 0.01^{\mathrm{b}, \mathrm{c}}$ & $2.50 \pm 0.02^{\mathrm{a}, \mathrm{b}}$ & $0.68 \pm 0.01^{\mathrm{c}, \mathrm{d}}$ & $0.47 \pm 0.01^{\mathrm{b}}$ \\
$4(200 \mathrm{mg})$ & $1.25 \pm 0.05^{\mathrm{a}, \mathrm{b}, \mathrm{c}}$ & $6.63 \pm 2.16^{\mathrm{b}, \mathrm{c}}$ & $0.17 \pm 0.02^{\mathrm{a}}$ & $0.45^{\mathrm{a}} \pm 0.02^{\mathrm{c}}$ \\
$5(400 \mathrm{mg})$ & $1.09 \pm 0.01^{\mathrm{a}, \mathrm{b}, \mathrm{c}}$ & $6.58 \pm 0.23^{\mathrm{b}, \mathrm{c}}$ & $0.44 \pm 0.02^{\mathrm{b}, \mathrm{c}}$ & $0.45 \pm 0.16^{\mathrm{c}}$ \\
$6(600 \mathrm{mg})$ & $0.89 \pm 0.05^{\mathrm{a}, \mathrm{b}}$ & $8.71 \pm 0.01^{\mathrm{c}}$ & $0.21 \pm 0.01^{\mathrm{a}, \mathrm{b}}$ & $0.61 \pm 0.01^{\mathrm{c}}$ \\
\hline
\end{tabular}

Values are means \pm Standard error of mean (SEM) and $\mathrm{n}=2$. Mean with different superscripts in a column are significantly different(p $<0.05)$. $N C=$ Normal Control, $P C=$ Positive Control, $N G C=$ Negative Control, $C a L=$ Centella asiatica leaves.

The serum liver function marker enzymes activities were observed to be significantly decreased $(\mathrm{p}<0.05)$ in all groups administered with the extract in a dose-dependent manner when compared to the untreated group (negative control) (Table 5).

Table 5 Effect of administration of ethanol extract of Centella asiatica leaves on liver enzymes of paracetamol-induce jaundiced albino rats

\begin{tabular}{llll}
\hline Group & AST(U/L) & ALT(U/L) & ALP(U/L) \\
\hline $1(\mathrm{NC})$ & $98.50 \pm 6.50^{\mathrm{c}, \mathrm{d}}$ & $20.50 \pm 0.50^{\mathrm{a}, \mathrm{b}}$ & $53.00 \pm 1.00^{\mathrm{a}, \mathrm{b}}$ \\
$2(\mathrm{NGC})$ & $115.00 \pm 2.00^{\mathrm{d}}$ & $35.80 \pm 0.60^{\mathrm{e}}$ & $85.00 \pm 1.00^{\mathrm{c}}$ \\
$3(\mathrm{PC})$ & $99.60 \pm 0.30^{\mathrm{c}}$ & $17.90 \pm 0.60^{\mathrm{a}}$ & $30.50 \pm 1.50^{\mathrm{a}}$ \\
$4(200 \mathrm{mg})$ & $63.50 \pm 12.50^{\mathrm{b}, \mathrm{c}}$ & $33.50 \pm 1.50^{\mathrm{d}, \mathrm{e}}$ & $64.50 \pm 1.50^{\mathrm{b}, \mathrm{c}}$ \\
$5(400 \mathrm{mg})$ & $52.00 \pm 8.00^{\mathrm{a}, \mathrm{b}}$ & $28.50 \pm 1.50^{\mathrm{c}, \mathrm{d}}$ & $69.00 \pm 13.00^{\mathrm{b}, \mathrm{c}}$ \\
$6(600 \mathrm{mg})$ & $21.50 \pm 0.50^{\mathrm{a}}$ & $23.50 \pm 0.50^{\mathrm{b}, \mathrm{c}}$ & $46.50 \pm 0.50^{\mathrm{a}, \mathrm{b}}$ \\
\hline
\end{tabular}

Values are means \pm Standard error of mean (SEM) and $\mathrm{n}=2$. Mean with different superscripts in a column are significantly different $(\mathrm{p}<0.05)$. $N C=$ Normal Control, $P C=$ Positive Control, $N G C=$ Negative Control, CaL $=$ Centella asiatica leaves . 
Levels of the liver function biomarkers; serum total protein, total bilirubin, conjugated and unconjugated bilirubin levels are shown in Table 6. There were significant increases in these biomarkers in the negative control group when compared to groups 1, 3 and CaL-extract treated groups. There was no significant difference observed in the albumin level of all groups.

Table 6 Effect of administration of ethanol extract of Centella asiatica leaves on liver function indices of paracetamolinduced jaundiced albino rats

\begin{tabular}{llllll}
\hline Group & TP(g/L) & ALB $(g / L)$ & TB( $\mu$ mol $/ \mathbf{L})$ & CB( $(\mu \mathrm{mol} / \mathbf{L})$ & UB $(\mu \mathrm{mol} / \mathbf{L})$ \\
\hline $1(\mathrm{NC})$ & $70.50 \pm 0.50^{\mathrm{b}, \mathrm{c}}$ & $35.50 \pm 0.50^{\mathrm{a}}$ & $10.80 \pm 0.10^{\mathrm{b}}$ & $4.46 \pm 0.02^{\mathrm{a}, \mathrm{b}, \mathrm{c}}$ & $6.34 \pm 0.08^{\mathrm{b}}$ \\
$2(\mathrm{NGC})$ & $71.00 \pm 1.00^{\mathrm{c}}$ & $36.00 \pm 1.00^{\mathrm{a}}$ & $21.64 \pm 0.03^{\mathrm{c}}$ & $8.52 \pm 0.03^{\mathrm{d}}$ & $13.12 \pm 0.06^{\mathrm{c}}$ \\
$3(\mathrm{PC})$ & $56.50 \pm 0.50^{\mathrm{a}}$ & $36.50 \pm 0.50^{\mathrm{a}}$ & $2.88 \pm 0.02^{\mathrm{a}}$ & $1.70 \pm 0.05^{\mathrm{a}}$ & $1.18 \pm 0.03^{\mathrm{a}}$ \\
$4(200 \mathrm{mg})$ & $57.50 \pm 4.50^{\mathrm{a}, \mathrm{b}}$ & $35.50 \pm 3.50^{\mathrm{a}}$ & $12.25 \pm 1.25^{\mathrm{b}}$ & $6.50 \pm 0.30^{\mathrm{c}, \mathrm{d}}$ & $5.75 \pm 0.95^{\mathrm{b}}$ \\
$5(400 \mathrm{mg})$ & $63.50 \pm 3.50^{\mathrm{a}, \mathrm{b}, \mathrm{c}}$ & $40.00 \pm 2.00^{\mathrm{a}}$ & $10.95 \pm 1.75^{\mathrm{b}}$ & $6.10 \pm 1.40^{\mathrm{b}, \mathrm{c}, \mathrm{d}}$ & $4.85 \pm 0.35^{\mathrm{b}}$ \\
$6(600 \mathrm{mg})$ & $70.5 \pm 0.50^{\mathrm{b}, \mathrm{c}}$ & $41.50 \pm 0.50^{\mathrm{a}}$ & $4.75 \pm 0.05^{\mathrm{a}}$ & $3.15 \pm 0.05^{\mathrm{a}, \mathrm{b}}$ & $1.60 \pm 0.10^{\mathrm{a}}$ \\
\hline
\end{tabular}

Values are means \pm Standard error of mean (SEM) and $\mathrm{n}=2$. Mean with different superscripts in a column are significantly different $(\mathrm{p}<0.05)$. NC = Normal Control, $P C=$ Positive Control, $N G C=$ Negative Control, CaL = Centella asiatica leaves.

Results of renal function indices are presented in Table 7. There was significant increasein serum creatinine and urea levelsin the negative control group when compared to group 1 and CaL-extract groups. Serum electrolytes levels were altered among the groups. Serum chloride and bicarbonate levels in group 2 were higher compared with the rest of the groups. Elevated levels of sodium and potassium were observed in CaL-extract treated groups compared with group 3.

Table 7 Effect of administration of ethanol extract of Centella asiatica leaves on kidney indices (mmol/L) of paracetamol-jaundiced albino rats

\begin{tabular}{|c|c|c|c|c|c|c|}
\hline Group & Urea & Creatinine & Potassium & Sodium & Chloride & Bicarbonate \\
\hline $1(\mathrm{NC})$ & $4.02 \pm 0.03^{a}$ & $125.00 \pm 1.00^{\mathrm{a}, \mathrm{b}}$ & $3.03 \pm 0.01^{\mathrm{a}}$ & $117.60 \pm 0.80^{\mathrm{a}}$ & $94.00 \pm 1.00^{c}$ & $24.00 \pm 1.00^{\mathrm{a}, \mathrm{b}}$ \\
\hline $2(\mathrm{NGC})$ & $8.59 \pm 0.02^{b}$ & $139.50 \pm 0.50^{\mathrm{a}, \mathrm{b}}$ & $4.45 \pm 0.05^{\mathrm{a}, \mathrm{b}}$ & $136.90 \pm 0.30^{\mathrm{a}, \mathrm{b}}$ & $108.00 \pm 1.00^{d}$ & $27.50 \pm 0.50^{\mathrm{b}}$ \\
\hline $3(\mathrm{PC})$ & $2.92 \pm 0.02^{\mathrm{a}}$ & $122.50 \pm 0.50^{\mathrm{a}}$ & $4.20 \pm 0.10^{\mathrm{a}, \mathrm{b}}$ & $125.40 \pm 0.40^{\mathrm{a}, \mathrm{b}}$ & $95.50 \pm 0.50^{c}$ & $25.00 \pm 1.00^{\mathrm{a}, \mathrm{b}}$ \\
\hline $4(200 \mathrm{mg})$ & $3.75 \pm 0.95^{\mathrm{a}}$ & $115.00 \pm 13.00^{\mathrm{a}}$ & $7.85 \pm 1.55^{\mathrm{a}, \mathrm{b}}$ & $155.00 \pm 10.00^{\mathrm{b}}$ & $82.50 \pm 1.50^{\mathrm{a}, \mathrm{b}}$ & $25.00 \pm 1.00^{\mathrm{a}, \mathrm{b}}$ \\
\hline $5(400 \mathrm{mg})$ & $4.55 \pm 0.25^{\mathrm{a}}$ & $127.50 \pm 2.50^{\mathrm{a}, \mathrm{b}}$ & $9.15 \pm 1.55^{b}$ & $160.0 \pm 12.00^{\mathrm{b}}$ & $92.50 \pm 4.50^{\mathrm{b}, \mathrm{c}}$ & $27.00 \pm 1.00^{\mathrm{b}, \mathrm{c}}$ \\
\hline $6(600 \mathrm{mg})$ & $7.05 \pm 0.05^{b}$ & $154.50 \pm 0.50^{\mathrm{b}}$ & $7.65 \pm 0.05^{\mathrm{a}, \mathrm{b}}$ & $145.00 \pm 0.00^{\mathrm{a}, \mathrm{b}}$ & $72.50 \pm 0.50^{\mathrm{a}}$ & $22.00 \pm 0.00^{\mathrm{a}}$ \\
\hline
\end{tabular}

\section{Discussion}

Medicinal plants and herbs have been used for ages for the purpose of enhancing and maintaining health [24].World Health Organization has recommended further research into medicinal plants with the potentials to alleviate disease conditions. In view of this, several medicinal plants with potential therapeutic properties necessary for the treatment of liver disease and other conditions associated with it are currently being evaluated [4, 25]. Among the indigenous medicinal plants which are traditionally used in the management of jaundice and other liver related disease conditions with little or no scientific data is Centella asiatica. This study therefore evaluated the potentiality of this plant in addressing this condition.

Paracetamol-induced liver toxicity, leads to oxidative stress. Results on the effect of ethanol extract of Centella asiatica leaves on blood glucose revealed that the paracetamol-induced jaundiced untreated group (group 2) had significantly high glucose level when compared with the silymarin and CaL-extract treated groups. Ogugua [26] reported that increase in glucose level has been associated with oxidative stress. Consequently, the significant increase in blood glucose level in the group 2 rats could be a consequence of the intrinsic oxidative stress and generation of free radicals 
Ogunka-Nnoka et al. / World Journal of Advanced Research and Reviews, 2020, 06(01), 244-254

which led to alteration in the functioning of pancreatic beta cells with concomitant impairment of insulin secretion thereby causing possible hyperglycemia in the rats administered with paracetamol. However, a significant decrease $(\mathrm{p}<0.05)$ in blood glucose levels was observed in groups administered with the standard hepatoprotective drug (group 3) and groups treated with CaL-extract respectively. These hypoglycemic effects of the CaL-extract could have been mediated either via induction of hyperinsulinemia (increased pancreatic insulin secretion) or increased peripheral utilization of glucose. The former mechanism appears more likely as the pancreatic beta-cells are involved in the synthesis, storage, and release of insulin, the peptide hormone that regulates carbohydrate, protein, and lipid metabolism[4].Furthermore, the oral hypoglycaemic effect of CaL-extract could be attributed to the array of phytochemicals present in the ethanol extract [27]. It has been shown that the biological activities of alkaloids and flavonoids include hypoglycaemic, hypolipidemic and hypotension effects among other biological activities [28].The presence of flavonoids in plant extracts have been reported to stimulate the secretion of insulin [29]. It has also been reported that flavonoids extracted from Lotus (Nelunbo nucifera Gaertn) leaf at doses of 50 and $200 \mathrm{mg} / \mathrm{kg}$ for $28 \mathrm{days}$ significantly decreased fasting blood sugar, serum total cholesterol and triglyceride levels and increased high density lipoprotein level in alloxan-induced diabetic mice[30].This findings agree with the reports by [4, 31].

The observed increase in lipid profile of jaundiced rats (group 2) is associated with increase in glucose levelas reported above. High glucose level alters lipid metabolism. Elevated levels of total cholesterol (TC), triglyceride (TG), low density lipoprotein (LDL) and very low density lipoprotein(VLDL-cholesterol) are associated with atherosclerosis[32]. In this study, jaundiced rats that received the various doses of CaL-extract and the reference drug (silymarin) had reduced TC, TG, LDL and VLDL-cholesterol levels when compared to the jaundiced untreated rats (group 2). The decrease in cholesterol concentration, might be attributed to the presence of some photochemicals especially saponins. Saponins have been reported to reduce the uptake of cholesterol in the gut through intra-lumenal physiochemical interaction and thereby help reduce cholesterol level in blood [33]. High density lipoprotein (HDL) concentration showed a significant increase $(\mathrm{p}<0.05)$ in the groups treated with CaL-extract and reference drug relative to the normal and negative controls. HDL inhibits the oxidation of LDL by transition metal ions, and also prevents 12-lipooxygenase mediated formation of lipid hydroperoxide [34].

The actual physiological status of animals can be diagnosed through use of blood parameters. For normal functioning blood constituents should be maintained at homeostatic concentrations under normal conditions. Results of haematological parameters showed a decrease in HB, RBC, PCV and platelets of the jaundiced rats compared to the normal control. The above conditions were reversed after the administration of silymarin and CaL-extracts to rats in groups 3 and 4-6 respectively. This reversal indicates that CaL-extract could exhibit some anti-anaemic properties with the phytochemicals, antioxidants and vitamins present [35]. The increase in PCV after the administration of CaL-extract, could be attributed to a possible induction of hematopoietic mechanism in response to the low PCV level resulting in the production of more blood cells. These results agree with the reports by Diallo et al.[36] on extracts of Tectona grandis which increased the concentration of red blood cells after induction with phenylhydrazine. The increase recorded for WBC after treatment with the extract was not significant at $200 \mathrm{mg} / \mathrm{kg}$ bw(group 4) dose level of CaL-extract. However, there were significant differences at dose levels of $400 \mathrm{mg} / \mathrm{kg} \mathrm{bw}$ (group 5) and $600 \mathrm{mg} / \mathrm{kg}$ bw (group 6). WBC counts usually increase rapidly following a foreign attack on the system by pathogens; the normal physiological response of the system will be to boost the body's defense mechanisms [37].

Antioxidants are substances when present at low concentrations, compared with those of an oxidizable substrate, significantly delays or prevent oxidation of that substrate [38]. The present study showed a decrease in the activities of catalase (CAT), superoxide dismutase (SOD) and reduced glutathione (GSH) levels of the negative control group as compared with group 1, 3 and 4-6. There was also an increase in malondialdehyde (MDA)levels of thenegative control group (group 2) and groups 5-6. These conditions, also confirms damage to the liver[28, 39].Upon theadministration of the ethanol leaf extracts of Centella asiatica,there were significant increases $(\mathrm{p}<0.05)$ in the activities of CAT, SOD and GSH of the treated groups when compared with the negative control group. These results conform to the reports by Upadhyay et al.,[40] and Ganie et al.,[41]. The mode of action of the ethanol leaf extracts of Centella asiaticain attenuating the damage of paracetamol induced toxicity may be due to the cell membrane stabilization and activation of antioxidant enzymes via de novo synthesis of SOD and CAT. MDA levels of the extract treated groups were significantly decreased $(\mathrm{p}<0.05)$ upon the administration of the CaL- extracts as compared with those of the negative control group.

To ascertain the status of a functional liver, the activity of the enzymes AST, ALT and ALP are basic biochemical markers that are usually measured. The liver is prone to xenobiotic-induced injury because of its central role in the metabolism of drugs and foreign compounds and its portal location within the circulatory system. The results of the present study indicates that there were elevated levels of these enzymes as well as other liver function parameters such as serum protein, bilirubin, conjugated and unconjugated bilirubin in the jaundiced rats. However, administration of ethanol extract of Centella asiatica, attenuated the activities of the serum enzymes as well as the other liver function indices. 
These results are in consonance with the reports of other researchers[42, 43].Increased levels of certain plasma proteins serve as an indication of a diseased condition in the liver arising from hepatitis B or C, human immunodeficiency virus (HIV) or bone marrow disorder. Bilirubin is produced when haemoglobin is released from red blood cells to form haem and globulin. Haem is metabolized to biliverdin which is transformed into bilirubin. The increased amount of bilirubin causes the yellow colour of the skin and conjunctiva [44].

The consistency of endogenous creatinine and urea production andexcretion at constant rate is an indication of renal function and nephrotoxicity [45]. The high levels of creatinine and urea observed with group 2 when compared to the treated groups' shows that the initial impairment of the renal clearance mechanism following paracetamol induced nepherotoxicity was ameliorated when the CaL extract was administered. Also, serum chloride and bicarbonate ions are group of electrolytes that can be used to asses renal functions [11].The significant increase in serum chloride and bicarbonate ions in group 2 may be an indication of possible impairment of tubular glomerula function.

\section{Conclusion}

Hepatic jaundice is a type of jaundice in which the basic defect lies within the liver mainly in the hepatocytes. Any condition in the liver leading to defect in excretion of bilirubin can cause hepatic jaundice and hepatotoxicity. This study demonstrated thepotentials of ethanol extract of Gotu kola (Centella asiatica) leaves in the treatment of jaundice triggered by paracetamol-induced hepatotoxicity in albino rats and justified the potency of this plantand its usage at the traditional levels for the treatment of jaundice.

\section{Compliance with ethical standards}

\section{Acknowledgments}

The authors would like to thank the Department of Biochemistry, University of Port Harcourt Rivers State, Nigeria for providing the facilities for this study.

\section{Disclosure of conflict of interest}

All authors declare that they have no conflict of interest.

\section{Statement of ethical approval}

All procedures performed in studies involving animals were in accordance with the Guidelines for the Care and Use of Laboratory Animals at the National Institute of the National Institute of Advanced Industrial Science and Technology (AIST). The Research Ethics Committee, University of Port Harcourt, Nigeria, approved the study protocol (Approval no. UPH/CEREMAD/REC/MM60/040).

\section{References}

[1] Arise RO, Akintola AA, Olarinoye JB and Balogun EA. (2012). Effects of aqueous extract of Nauclea latifolia stem on lipid profile and some enzymes of rat liver and kidney. International Journal of Pharmacology, 8(5), 389-395.

[2] Ogbonnia SO, Make GO, Nkemehule FE, Emordi JE, Okpagu NC and Ota DA. (2014). Acute and subchronic evaluation of aqueous extracts of Newbouldia laevis (Bignoniaceae) and Naucle alatifolia (Rubiaceae) roots used singly or in combination in Nigerian traditional medicines. British Journal of Pharmacology and Toxicology, 5, $55-62$.

[3] Ogbonnia SO, Nkemehule FE and Annika EN. (2009). Evaluation of acute and subchronic toxicity of Stachytarpheta angustifolia(Mill) Vahl (Fam. Verbanaceae) extract in animals. Journal of Biotechnology, 8, 17931799.

[4] Ogunka-Nnoka CU, Okolo LU and Uwakwe AA. (2020). Ameliorative potentials of aqueous extracts of leaf and stem of Ipomoea involucrata on selected biochemicals in experimental diabetic rats.Basic and Clinical Pharmacology, 9(1), 9-15.

[5] Srinath J and Laksmi T. (2014). Therapeutic potential of Spilanthes acmella- A dental note. International Journal ofPharmaceutical Science Review and Research, 25, 151-153. 
[6] Myung-Joo C, Hong-Mei Z, Jaye MK, Kye W, Lee Y, Hwa P and Don HL. (2016). Protective Effect of Centella asiatica leaf extract on Dimethylnitrosamins-induced liver injury in rats. Molecular Medicine Reports, 14, 4521-4528.

[7] Shanghai PR. (1977). Jiangsu new medical college. Dictionary of Chinese Material Medica. China: Shanghai Scientific and Technical Publishing House, 1874.

[8] Sushma T, Sangeeta G and Gambhir IS. (2011). Centella asiatica: A Concise Drug Review with Probable Clinical Uses.Journal of Stress Physiology and Biochemistry, 7(1), 38-44.

[9] Yusuf N, Martina R, Ahmad SS, Pulungan NP and Diky SD. (2018). Antimicrobial Activities of Centella asiatica Leaf and Root Extracts on Selected Pathogenic Micro-organisms. Journal of Medical Sciences, 18, 198-204.

[10] Kashmira J, Gohil JAand Anuradha KG. (2010). Pharmacological Review on Centella asiatica: A Potential Herbal Cure-all. Indian Journal of Pharmaceutical Sciences,72(5), 546-556.

[11] Olatunji BA and Ogunka-Nnoka CU. (2019). Therapeutic Effect of Ethanol extract of Anthocleista vogelii stem bark in the treatment of jaundice on paracetamol-induced Hepatotoxicity in Adult wistar rats. Journal of Advances in Medical and Pharmaceutical Sciences, 21(4), 1-11.

[12] Beckingham IJ and Ryder SD. (2001). ABC of diseases of the liver, pancreas and biliary system: investigation of liver and biliary disease. British Medical Journal,322, 33-36.

[13] Patil RA and Makwanna AB. (2015). Hyperbilirubiinnemic and wound healing activity of aqueous extract of Calotropis procera leaves in wistar rats. Indian Journal of Pharmacology, 47(4), 398-402.

[14] Ekor M. (2013). The growing use of herbal medicines: issues relating to adverse reactions and challenges in monitoring safety. Frontiers in Pharmacology, 4, 177.

[15] Drucker RF, Williams DR and Price CP. (1984). Quality Assessment of Blood Glucose Monitoring use outside the hospital Laboratory. Journal of Clinical Pathology, 36 (9), 48-53.

[16] Friedewald WT, Levey RI and Fredrickson DS. (1972). Estimation of the concentration of low density lipoprotein cholesterol in plasma, without use of the preparative ultracentrifuge. Clinical chemistry, 18(6), 499-502.

[17] Anigboro AA, Avwioroko OJ, Ohwokevwo, OA and Nzor JN. (2018). Phytochemical constituents, antidiabetic and ameliorative effects of Polyalthia longifiola leaf extract in Alloxan - induced diabetic rats. Journal of Applied Science Environmental Management, 22, 993-998.

[18] Tietz NW, Pruden FL and Siggard-Anderson O. (1986). Electrolytes blood gasses and acid base balance. In: Textbook of Clinical Chemistry, Saunders, Philadelphia, 118-119.

[19] Wilson WD and Ball EG. (1928). A Study of the Estimation of Chloride in Blood and Serum. Journal of Biological Chemistry, 79, 221-227.

[20] Aebi H.(1974). Catalase. In: Bergmeyer HV (ed.), Methods in Enzymatic Analysis. New York, Acadamic press, USA, 2, 674-684.

[21] Misra HP and Fridovich I. (1972). The role of superoxide anion in the autoxidation of epinephrine and a simple assay for superoxide dismutase. Journal of Biological Chemistry, 247, 3170.

[22] Moron MS, Depierre JW and Mannervik B. (1979). Levels of glutathione, glutathione reductase and glutathione Stransferase activities in rat lung and liver. Biochimica Biophysica Acta, 582, 67-78.

[23] Niehius WG and Samuelsson B. (1968). Formation of phosholipid arachiodonate during microsomal lipid peroxidation. European Journal of Biochemistry, 6, 126-130.

[24] Muriithi NJ, Maina GS, Mugendi MN, Maina MB, Kiambi MJ, Kelvin JK, Umar A, John MK, Ann NW, Abdirahman YA, Piero, N and Eliud NM. (2015). Determination of Haematological Effects of Methanolic Leaf Extract of S.incanum in Normal Mice. Pharmaceutical Annal Acta, 6, 429.

[25] Oztur M, Akdogan M, Keskin I, Kisioglu AN, Oztas S and Yildiz K (2012). Effect of Silybum marianum on acute hepatic damage caused by carbontetrachloride in rats. Biomedical Research, 23, 268-274.

[26] Ogugua VN. (2000). Assessment of some parameters of oxidative stress in alloxan induced diabetic rabbits. Ph.D Thesis, Department of Biochemistry, University of Nigeria, Nsukka, 128-134.

[27] Essiet UA and Ukpong UJ. (2014). Comparative Phytochemical, Nutrient and Antinutrient of Stems of Ipomoea involucrata Beauv, Ipomeoa tritoba and Ipomoea batatas. American Journal of Food and Nutrition,4, 71-76. 
[28] Oladele SB, Ayo JO and Adaudi AO. (2011). Medicinal and physiological properties of flavonoids, coumarin derivatives and anthraqoinones of plant origin. West African Journal of Pharmacology and Drug Research, 11, 15-20.

[29] Schimizu M, Ito T, Rshima S, Mayashi T, Arisawa M, Morita-Kurukowa S and Ito HY. (1988). Inhibition of lens aldose reductase by flavonoids. Phytochemistry, 23, 1886-1888.

[30] Taoying Z, Denghong L, Xingyuan L and Yunbo L. (2009). Hypoglycemic and hypolipidemic effect of flavonoids from lotus(Nelunbo nuficera Gaertn)leaf in diabetic mice. Journal of Medicinal Plant Research, 3(4), $113-137$.

[31] Ojulari LS, Oyeniyi RO and Owoloye BV. (2014). Effect of Hibiscus sabdariffa on Blood Glucose and Serum Electrolytes in rats. Journal of Dental and Medical Sciences, 13 (11),60-62.

[32] Murray RK, Granner DK, Mayes PA and Rodwell VW. (2003). Harper's Illustrated Biochemistry. A Lange Medical Book, 20th Edition. McGraw-Hill, 102-583.

[33] Price KR, Johnson LI and Fenwick H. (1987). Chemical and Biological Significance of Saponins in Foods and Feeding Stuffs. Critical Review of Food Science and Nutrition, 26(1), 127-135.

[34] Nofer JR, Kehrel B, Fobker M, Levkau B, Assmann G and vonEckardstein A. (2002). HDL and Atherosclerosis: beyond reverse cholesterol transport. Artherosclerosis, 161, 1-16.

[35] Onyeabo C, Achi NK, Ekeleme-Egedigwe CA, Ebere CU and Okoro CK. (2017). Haematological and Biochemical Studies on Justica carnea leaves extract in Phenylhydrazine induced-Anaemia in Albino Rats.Acta Scientiarum Polonurum Technology Aliment,16(2), 217-230.

[36] Diallo A, Gbeassor M, Vovor A, Eklu-Gadegbeku K, Aklikokou K and Agbonon A. (2008). Effect of Tectona grandis on phenylhydrazine induced-anaemia in rats. Fitoterapia, 79, 332-336.

[37] Eyong EU, Umoh IB, Ebong PE, Eteng MU, Antai AB and Akoa AO. (2004). Haemotoxic effects following ingestion Nigerian crude oil and crude polluted shellfish by rats. Nigerian Journal of Physiological Science, 19(1-2), 1-6.

[38] Kooter IM. (2004). Inventory of Biomakers for oxidative stress. RIVM report 630111001.

[39] Khan TH and Sultana S. (2017). Antioxidant and hepatoprotective potential of Aegle marmelos Correa against CCl4-induced oxidative stress and early tumor events. Journal of Enzyme Inhibitory and Medical Chemistry, 24, 320-327.

[40] Upadhyay G, Malik J, Joshi R, Lakshmayya PT and Singh UK. (2017). Hepatoprotective Potential of Lyophilized Hydro-Alcoholic Extract of Roylea elegans Wall. Against CCL4 and PCM Induced Hepatotoxicity in Wistar Rats. Annals of Pharmacolology Pharmcognosy, 2, 1045.

[41] Ganie SA, Haq E, Masood A and Zargar MA. (2010). Amelioration of carbon tetrachloride induced oxidative stress in kidney and lung tissues by ethanolic rhizome extract of Podophyllum hexandrum in Wistar rats. Journal of Medicinal Plants Research, 4,1673-1677.

[42] Tseng TH, Kao TE, Chu CY, Chou FP, Lin WL and Wang CJ. (1997). Protective effects of dried flower extracts of Hibiscus sabdariffa L against Oxidative stress in rats primary hepatocytes. Food and Chemical Toxicology, 35(12), 1159-1164.

[43] Omoniwa BP and Luka CD. (2012). Antidiabetic and Toxicity Evaluation of Aqueous Stem extract of Ficus aserifolia in Normal and Alloxan-Induced Diabetic Albino Rats. Asian Journal of Experimental Biological Science, 3(4), 726-732.

[44] David GL and Michael AL. (2014). Quantitative Assessment of Multiple Processes responsible for bilirubin homeostasis in Health and Disease. Clinical and Experimental Gastroenterology, 7, 307-328.

[45] Knapp ML and Hadidi O. (1987). Investigation into negative Interference by Jaundiced plasma creatinine determination. Annals of Clinical Biochemistry, 2485-2497.

\section{How to cite this article}

Ogunka-Nnoka CU, Igwe FU, OvuworieFP, Eme LO and Niabari B. (2020). Potential of Centella asiatica leaf extract in the management of paracetamol-induced jaundice in albino rats. World Journal of Advanced Research and Reviews, 6(1), 244-254. 